\title{
Cargo Delivery without Presentation of the Bill of Lading in Chinese Maritime Law and Practice
}

\author{
Vehbi S. Ataergin \\ Dean Professor of Law School at Near East University
}

\begin{abstract}
This chapter examines the Chinese practice of delivery of the cargo without presentation of the bill of lading and the law and regulations governing that practice, and in the gaps left by laws and regulations, the approach established by the legal authorities and maritime courts. The necessities and causes for this risky action and possible suggestions will be considered, as will the approach of statute and judiciary. Potential and desirable reform will be discussed in light of the Rotterdam Rules. It is concluded that in order to facilitate cargo delivery, there would be a need to provide detailed legal guidance applicable to the many situations where the requisite documentation has failed to materialise.
\end{abstract}

Key words: Maritime law, international trade law, Chinese maritime law, cargo delivery, bill of lading.

\section{Introduction}

Much carriage of goods by sea is related to an international sale contract. The seller has two separate sets of duties to perform in accordance with the international sale contract: namely, physical duties and documentary duties. Physical duties include description, condition of the goods, time of delivery, and place of delivery of the goods. Documentary duties include the transport and sale documents containing the true facts of the sale and carriage contracts. And the bill of lading retains the crucial role of representing the goods in transit; and enabling the seller to be paid through letters of credit; the bill of lading also safeguards the buyer on shipment terms against loss or damage in transit by giving him rights against the carrier since the holder of it can request the cargo from the carrier depending on its terms. But what if there is no availability of it at the discharge port?

There is a practice in carriage of goods by sea of complying with a request from the consignee for the

Corresponding author: Vehbi S. Ataergin, LLM(Soton), Ph.D.(Marmara), Visiting Professor, Shanghai Maritime University School of Law (for his full credentials https://uk.linkedin.com/pub/dr-vehbi-selim-ataergin/22/920/ba4). Research fields: maritime law, international trade law, marine insurance and arbitration. release of the cargo on board without presentation of the bill of lading, although such practice is the opposite of what the carrier should do to legitimise the delivery and protect itself from liabilities. Against the background of vivid examples of carriers being sued for damages and going into bankruptcy, the practice remains the method of choice for actors in international trade. Shipping practice allows and perhaps expects this phenomenon to take place-China is no different in this regard.

In China, delivery without production of the bill of lading appears to take place in 30 percent of bulk general cargo trade, 50 per cent in containerised transportation, and 70 per cent in bulk carriage of liquids. The number of disputes concerning delivery without a bill of lading has reached 5 per cent of the total number of maritime cases in the Supreme People's Court. At present, the number of cases on the delivery of goods without the bill of lading is equivalent to the total sum of disputes in other countries around the world. ${ }^{1}$

\footnotetext{
1 Those statistics are referred in Shoujie Liu, "Interpretation on Regulations Promulgated by the Supreme People's Court of P.R.C. on Trial of Cases of the Delivery of Goods without Production of Original Bill of Lading" (2009) 20 (3) Annual of China Maritime Law 22.
} 


\section{Presentation Rule}

Once the bill of lading has been issued by the carrier to the shipper and transferred to a third party holder by the shipper, it stands for a promise made by the carrier to the holder. In most cases it will contain a clause to the effect that: "One original bill of lading must be surrendered duly endorsed in exchange for the cargo or delivery order". ${ }^{2}$ The carrier's delivery of the goods to the holder of the bill of lading is thus expected; this is referred to as the presentation rule. ${ }^{3}$ This duty of delivery upon the presentation of the bill of lading is also a right for the carrier since he has an absolute discretion (in fact he must) to refuse delivery in the absence of presentation, even though the claimant maybe the real owner of the goods, as it might occur if the bill of lading is lost or stolen. This is so because the right to delivery is vested in the bill of lading ${ }^{4}$ which by endorsement and delivery gives the holder constructive possession of the goods. ${ }^{5}$

Universally, particularly at common law, the consequences of delivering the cargo without the bill would be harsh on the carrier, who will lose limitation rights and P\&I Club coverage and will incur liability not only in contract but also in tort. ${ }^{6}$ It is also worth noting that if the carrier releases the goods on the basis of a forged bill of lading, the latter is considered to be null and void and therefore the delivery will be deemed

\footnotetext{
${ }^{2}$ https://www.bimco.org/en/Chartering/Clauses_and_Document s/Documents/Bills_of_Lading/CONLINEBILL2000.aspx. Last accessed on 5 August 2015.

3 London Joint Stock Bank Ltd v British Amsterdam Maritime Agency Ltd (1910) 11 Asp MLC 571.

4 The breach of this duty deprives the carrier of contractual exclusions and limitation rights which would otherwise be available under the contract evidenced by or contained in the bill of lading as held in Sze Hai Tong Bank v Rambler Cycle Co (1959) AC 576. See also The Ines [1995] 2 Lloyd's Rep.144.

5 Further details regarding the presentation rule at common law and COGSA 1992, see Charles Debattista, Bills of Lading in Export Trade (3rd edn, Tottel Publishing 2009) para. 2.16-2.17. Concerning the concept of a lawful bill of lading holder, see COGSA Section 2 (1) (a) and Section 5 (2) according to which the holder must be a person with possession of the bill of lading.

${ }^{6}$ Aikens et al., Bills of Lading (Informa 2006) p. 99.
}

to have been made without it. ${ }^{7}$ In common law jurisdictions, the carrier also remains liable to the lawful bill of lading holder in all circumstances for delivery against the surrender of a false bill of lading, ${ }^{8}$ although some recovery may take place from the presenter of the false bill of lading. ${ }^{9}$

\section{Delivery without Production of the Bill of Lading: Law and Practice}

The risk resulting from delivery without presentation of the bill of lading is that there might be a future request for delivery from the holder of the bill of lading, asking the same cargo to be delivered. ${ }^{10}$ In such a situation, the previous delivery will amount to a misdelivery (delivery to the wrong person); ${ }^{11}$ however, the carrier may wish to take its chances and deliver without requesting presentation of the bill of lading in the hope that the consignee is a true receiver. ${ }^{12}$ The carrier may agree to deliver the cargo without presentation of the bill of lading in return for compensation or security such as Letter of indemnity and/or bank guarantee ${ }^{13}$ or may deliver the cargo against the presentation of a document which is not in fact an original. ${ }^{14}$

In such cases the innocent party, suffering loss, may initiate legal action; although it might be considered

\footnotetext{
${ }^{7}$ Motis Exports Ltd v Dampskibsselskabet AF 1912 [2000] 1 Lloyd's Rep 211. This decision emphasises that the courts are not prepared to undermine the integrity of the bill as the key to the floating warehouse. See Gaskell, p. 423.

8 Trafigura Beheer BV v Mediterranean Shipping Co SA (The Amsterdam) [2007] 2 Lloyd's Rep 622.

9 Mitsui OSK Lines (Thailand) Co Ltd v Jack Fair Pty Ltd [2015] FCCA 558.

10 Yuzhuo Si, Monographic Study of Maritime Law (Dalian Maritime University Press 2002) pp.194-198.

${ }^{11}$ For the contrary view, see Yifan Liao, "Delivery without Bill of Lading Is Not Equal to Misdelivery" (2001), Proceedings of the China Lawyers 2001 Maritime Symposium 40.

12 Yuanmin Lin, Philip Yang on Shipping Practice (Dalian Maritime University Press 1995) 233.

13 A deeper analysis can be seen in Ting Lei, "On the Nature and Legal Liability of Delivery without the Original Bill of Lading"(2000), Annual of China Maritime Trial, 123.

14 Qingde Kong, "Conditions for Delivery without Bill of Lading", Proceedings of the China Lawyers 2001 Maritime Symposium 59.
} 
that if the carrier delivers the goods without the bill of lading to someone who in fact has the right to take delivery of the goods the result is not a "misdelivery", because that term refers only to delivery to a party who does not have the right to take the goods. ${ }^{15}$ However, on a broader approach, any delivery not involving the bill of lading would be considered a "misdelivery". ${ }^{16}$ There are a number of situations wherein the carrier might be inclined to deliver without presentation, which will be outlined in the following.

First, bank procedures are sometimes unable to keep up with the speed of modern shipping. Increasing numbers of ports and technological improvement have gradually made the traded goods move faster than the documents. This is especially true for China, where administration is complicated, ports are within close range and the transport documents may remain in the hands of the bank. Delay is likely to result from bank procedures to the detriment of the buyer and the seller as well as the carrier. This causes additional running costs and loss of earnings from planned subsequent carriage for the carrier and loss of marketing options for the consignee.

The carrier may therefore accept the risk of delivering the cargo without presentation of the bill of lading in the joint interests of the carrier and consignee, resulting in a deviation from the correct course established by law and international custom. Since not all discharging ports are equipped with adequate warehouses to accommodate various kinds of goods, it is now common practice in containerised transportation

15 Yuzhuo Si, Yuechuan Jiang, "A legislative attempt on the delivery without the original bill of lading", Transport Law Draft of UNCITRAL, Provisions on Delivery without bill of lading, Annual of China Maritime Law, 2003, 14/1.

16 Gang Fang Liu, The Causesand Solution toDeliveryofGoodswithout Bill oflading in China, May 2012, p. 3.

(works.bepress.com/cgi/viewcontent.cgi?article=1000\&context =gangfang_liu). Therefore, the situation of misdelivery could be summarised as when the carrier, in violating the law or agreement under the contract, delivers the goods without bill of lading and damages the rights of the true holder. and bulk liquid carriage. ${ }^{17}$

Second, in some countries, cargo must first be delivered to port authorities or customs, and only then to the consignee. ${ }^{18}$ Carriers fulfil their duty of transport by delivering the goods to customs and obtaining customs confirmation, allowing the consignees to then take delivery of the goods without bills of lading. This was the past practice of port authorities in coastal regions in China. ${ }^{19}$ Given that this runs contrary to international custom and practice of delivery against presentation of the original bill of lading, at the enactment of the Maritime Code in 1992, the duty of delivery against presentation of the original bill of lading was written into the Code, with the result that any rules and regulations of local authorities became unlawful. ${ }^{20}$

Third, the consignor may have difficulties supplying complying documents on time in a particular case. The seller must have the correct documents from the carrier in order to fulfil its duties under the sales contract. Errors on the part of the seller, as consignor, may result in critical discrepancies and face the bank's rejection of

17 Delivery without production takes place in almost $100 \%$ in the transport of expensive materials, such as minerals and oil. See Yuzhuo Si et al., "Theory and Practice on Delivery without Bill of Lading - The Proper Nature of Bill of Lading" (2000), Annual of China Maritime Law 18.

${ }^{18}$ Mexico and South American countries require the carrier to deliver the cargo to the customs or port authorities so it is almost impossible for the carrier to hand the cargo to the consignee against bill of lading, cited at Hui Jie Luo and Miao $\mathrm{Li}$, "Reviewing Recent Developments in Chinese Maritime Law" (2010) 41(3) Journal of Maritime Law and Commerce 407.

19 Dalian Port Committee has issued two papers to make the delivery of cargo without bill of lading rightful. See the Supplementary Provisions on Taking Delivery against Original Bill of Lading of Marine Goods Imported, 1986 and 1990 cited at Jingxin Guan, "On the Nature of Delivery without Bill of Lading", Proceedings of the China Lawyers 2001 Maritime Symposium 7.

${ }^{20}$ In a number of cases, forged bills of lading have been used to obtain delivery of cargo, possibly with the knowledge of Customs officials, agents' clerks or employees of the terminal operators. In at least one case, a high level anti-corruption investigation was conducted resulting in a number of Customs officials being arrested; http://www.nepia.com/news/circulars/bills-of-lading-delivery-o f-cargo-the-republic-of-korea-and-the-peoples-republic-of-chin a/. 
the documents, causing serious delay in the dispatch of the documents to the buyer.

The seller may ask the carrier to sign a back-dated bill of lading corresponding to the shipment date stipulated by the letter of credit. In such circumstances reissuing the documents or amending the letter of credit to reflect the actual transaction would delay the circulation of the bill of lading, with the result that the goods will have already arrived at the destination. The consignee will then demand delivery against a photocopy of the bill of lading together with a letter of indemnity. With the aim of fulfilling the duty of transport as soon as possible, the carriers may deliver without the bill of lading.

Fourth, the consignee may change the payment method from payment by letter of credit or cash against documents to telegraphic transfer. The seller will then require the carrier to modify or re-issue a fresh bill of lading, where the bill of lading contains a reference to the letter of credit or otherwise to the method of payment on its face. In such circumstances, the arrival of the reissued bill of lading may be further delayed and the consignor may request the carrier to deliver the goods to the consignee without the bill of lading. ${ }^{21}$

Fifth, the consignee may decline to take delivery of the goods for any of below reasons; a sudden drop in the market price of the goods; or the cargo may be damaged and the expenses for dealing with such goods may exceed their remaining value; or the consignee may not have found the next buyer; or may not have sufficient funds to pay the opening bank; or there may be no warehouse facility available to store the cargo; or the government may have banned export of the commodities in question by the time the vessel arrives, preventing onward sale. ${ }^{22}$

Sixth, the carrier may decide to retain the full set of bills of lading, provided that the consignor agrees thereto, as security against the outstanding debts owed

\footnotetext{
${ }^{21}$ However, it is the consignor's responsibility to send the bill of lading to the consignee.

22 Export bans have featured heavily in cases of cargoes shipped from Ukraine and Russia.
}

to the carrier, making the bill of lading unavailable to the consignee. ${ }^{23}$

For any of the above reasons, each of which is a commonplace scenario, the bill of lading may not be available at the discharge port in time to serve its core function of evidence of entitlement to the cargo.

\section{The Chinese Approach to Delivery without the Bill of Lading}

Chinese statute is arguably unprepared for the type of situation described, leaving a gap to be filled judicially. Relevant statutes, guidelines and judicial attempts to manoeuvre the voids in between will be discussed in the following.

\subsection{Statutory Approach}

Under Chinese law, the position is as follows. ${ }^{24}$ The Maritime Code contains no express provisions about the delivery of cargo without presentation of the bill of lading. However, Article 71 defines the bill of lading as "A bill of lading is a document which serves as an evidence of the contract of carriage of goods by sea and the taking over or loading of the goods by the carrier, and based on which the carrier undertakes to deliver the goods against surrendering the same."

The official translation appears to suggest that not just "presentation" but "surrender" of the bill of lading is required. However the original Chinese text does not contain any equivalent of the words surrender or presentation. ${ }^{25}$ Given that presentation of the bill of

\footnotetext{
23 As in Trucks \& Spares Ltd $v$ Maritime Agencies (Southampton) Ltd [1951] 2 All ER 982 where the buyer was denied an interim order by the Court of Appeal for delivery without bill of lading.

${ }^{24}$ There are four codes that may influence maritime practice: General Principles of the Civil Law of the People's Republic of China promulgated on 12 April 1986, Contract Law of the People's Republic of China promulgated on 15 March 1999, Regulation on the Administration of Domestic Water Transport promulgated on 26 September 2012 by the State Council and issued on 13 December 2012 and took effect on 1 Jan 2013. "Provisions on the Administration of Domestic Water Transport" promulgated by the Ministry of Transport on 3 January 2014 and amended on 12 May 2015.

${ }^{25}$ A literal translation from the Chinese version is "...a bill of lading is a document that the carrier guarantees to deliver the
} 
lading is thus a precondition for the delivery of the cargo under applicable conventions and enacted domestic law, any delivery without presentation of the bill of lading appears to be misdelivery under the statutory approach.

Article 78 of the Maritime Code provides that the rights and duties as between the carrier and holder of the bill lading are to be determined by its own clauses; accordingly, presentation may be sought. Further support for this obligation is provided by Article 81 of the Maritime Code, which reads: "Unless notice of loss or damage is given in writing by the consignee [to] the carrier at the time of delivery of the goods by the carrier to the consignee, such delivery shall be deemed to be prima facie evidence of the delivery of the goods by the carrier as described in the transport documents and of the apparent goods order and condition of such goods." Here the phrase "...as described in the transport documents..." implies that a copy of the bill of lading should be at hand at the time of delivery. In fact, it appears to be common practice among Chinese judges to regard the presentation rule as a statutory obligation of the carrier. The title function is widely considered determinative among Chinese judges; indeed the second sentence of Article 71, "A provision in the document stating that the goods are to be delivered to the order of a named person, ${ }^{26}$ or to order, or to bearer, constitutes such an undertaking" lends further support to the function of the bill of lading as a document of title.

With a view to consolidating practice in the application of the Maritime Code on this point, the

corresponding cargo according to it." The original Chinese version of the text does not mention "surrender". The official English translation, however, used the word "surrender" instead which be seen at http://english.mofcom.gov.cn/aarticle/lawsdata/chineselaw/200 211/20021100050726.html (last accessed on 11 August 2015). This suggests that the translator does not perceive any difference between "presentation" and "surrender", although "surrender" of the document in exchange for the goods suggests that the carrier will retain the bill, whereas "presentation" involves demonstration only of the document and does not mean that the carrier will retain it.

${ }^{26}$ A straight bill of lading.
Supreme Court issued the Provisions of the Supreme People's Court on certain Issues concerning the Application of law to the Trial of Cases involving Delivery of Goods without an Original Bill of Lading. ${ }^{27}$ Article 2 of the Provisions provides that in delivering the goods without production of an original bill of lading, the carrier infringes the rights of the holder of the bill of lading. ${ }^{28}$

\section{Judicial Approach}

\subsection{The Requirement of a Bill of Lading}

Guidance on the law may also be derived from judicial decisions. In Xingli Co Guang'ao Co v India International Corp, Malaysia Balapuer Corp and others ${ }^{29}$ the Supreme Court concluded that the bill of lading is a document of title, and the holder of the a bill is the owner of the goods there under. ${ }^{30}$ Here the presentation rule was applied strictly. In Huarun Com. of Materials of Textile Hong Kong v. Zhanjiang Shipping Agency Com. Guangzhou, ${ }^{31}$ it was held that the person who holds the bill of lading legally owns the property to the goods. ${ }^{32}$

Another decision of interest was issued by the Shanghai Maritime Court in Zhong Cheng Ningbo Import and Export $v$ Shanghai Asia Pacific International Containership Warehousing and Transport Co. Ltd. ${ }^{33}$ The freight forwarder issued a

${ }^{27}$ It entered into force on 5 March 2009 and addressed some important features of the presentation rule under Chinese Law. ${ }_{28}$ http://www.court.gov.cn/fabu-xiangqing-56.html. Last accessed on 6 August 2015.

${ }^{29}$ (1991) 01 Gazette of the Supreme Court of PRC 44.

30 For a fuller review of this and some of the following decisions in English, see Yingying Zou, "Delivery of Goods by the Carrier under the Contract of Carriage by Sea - a Focus on China" (Ph.D. thesis, Erasmus University Rotterdam 2005), Chapter 5, available online at repub.eur.nl/pub/6943 (last accessed on 11 August 2015).

${ }^{31}$ Cited at $\mathrm{Hu}$ Zheng-Liang (James $\mathrm{Hu}$ ) \& Cao Ching, "A Reconsideration on the Functions of the Bill of Lading as a Document of Title" (1999) 7 Annual of China Maritime Law, 53.

${ }^{32}$ Yingying Zou, 'op cit, p. 153.

${ }^{33}$ For a salient English summary of this case, the main issues were the identification of the carrier and the shipper's title to sue under the bill of lading, see Greg Yang \& Mei Tong, "Delivery Without Bills of lading" at Steamship Mutual, May 
"to order" bill of lading "as agent of the carrier". The buyer failed to pay for the goods and the seller sought to take delivery at the discharge port. It was held that a claim for delivery with the presentation of only one original bill of lading was defective. The two decisions reflect judicial strictness on the part of Chinese judges in relation to delivery against production of the bill of lading.

\subsection{Agreement in Charter Contract}

Another question would be whether an agreement in the charter contract giving the carrier the power to deliver the cargo without bill of lading is effective.

In An Steel International Trade Co. v Woodtrans Navigation Corp., Sunwai Navigation $S A{ }^{34}$ it was concluded that the charterer was not entitled to give the master the instruction to deliver without the bill of lading, and this instruction also breached the compulsory obligation of the carrier to deliver against the original bill of lading. Where there is voyage charterparty in question this result may get unanimity. However, where a time charterparty is in operation it is not uncommon for charterers to instruct the master to deliver the cargo without the bill of lading. ${ }^{35}$

Where such a clause is present in the bill of lading it may cease to bear the features of a bill of lading as a document presented for deliveryand will simply operate as a receipt for the goods and as evidence of the contract of carriage. Therefore, the carrier may avoid the rule of presentation as a prerequisite for delivery. ${ }^{36}$

\footnotetext{
2008.

http://www.steamshipmutual.com/publications/Articles/Ningbo 0508.html> accessed on 3 August 2015.

${ }^{34}$ Civil Judgment No. 6 [2000] of the Supreme Court of the People's Republic of China; http://en.pkulaw.cn/display.aspx?cgid=117507532\&lib=case. Last accessed on 7 August 2015.

35 The Delfini [1990] 1 Lloyd's Rep. 252. Whereas a letter of indemnity can safeguard the carrier.

${ }^{36}$ However, the issue may be argued to the contrary. The terms on the back of the bill of lading are deemed to be standard terms, and the carrier must remind the party who accepts the bill to note exclusion clauses or restriction of its liabilities, and the standard terms exempt the carrier from his liabilities, weights the liabilities of the holder or other parties shall be
}

Equally, the carrier can arguably invoke the terms on the back of the bill of lading as grounds for discharge of his liability under the presentation rule. ${ }^{37}$ Such clauses would arguably protect carriers delivering the goods without bill of lading. ${ }^{38}$

It would be good to refer to The Sormovskiy $3068^{39}$ here again, where a term is implied into the bill of lading that the master must deliver cargo without production of an original bill of lading in circumstances where the master has been reasonably satisfied both that the person seeking delivery of the goods is entitled to possession and he was supposed to be named on the bills of lading if presented.

However, where a clause in a charterparty contract has been incorporated into the bill of lading by a choice of law clause, the carrier arguably cannot avail itself of such clauses to deliver without production of the bill of lading, if the holder has no means of obtaining knowledge of the clauses in a charterparty to which it is not a party. In The China Bank case, the judge rejected the bank's claim, who was a third party in the sale contract, yet the bank was regarded being aware of the sale contract, as it was referred in the letter of credit and therefore the bank should have known the special term allowing the carrier to delivery without bill. Therefore, one cannot draw a conclusion from this

\footnotetext{
"null and void"; see the Contract Law of the PRC Article 39, cited at Yingying Zou, "Delivery of Goods by the Carrier under the Contract of Carriage by Sea, a Focus on China" (Ph.D. thesis, Erasmus University Rotterdam 2005) 180. Therefore, with statutory authorisation, the validity of the exemptions would not be doubted. Hence a new CLC legislation is in need. 37 As an example of this clause: "The responsibilities of the carrier whether as carrier or bailee of the goods shall be deemed to commence only when the goods are loaded on the ship and to cease absolutely after they are discharged therefrom" in Sze Hai Tong Bank Ltd v Rambler Cycle Co Ltd (The SS Glengarry) [1959] 2 Lloyd's Rep. 114.

38 A provision can be put into the CMC indicating that the carrier shall remind the party, who accepts the bill to take care of the clauses of exclusion or restriction of its liabilities, and the standard terms exempt the carrier from his liabilities, weights the liabilities of the holder or other parties. However, existing article 41 of the Contract Law of the PRC which stating the principle of contra proferentem remains contrary with such a draft and all such clauses shall be null and void; cited at Yingying Zou p 180.

39 [1994] 2 Lloyd's Rep 266.
} 
decision that the carrier can do the same against the bona fide holder. $^{40}$ It is known that English courts have generally rejected the use of charterparty clauses incorporated into bills of lading and allowing for delivery on the basis of an indemnity as a defence against a case of wrongful delivery. ${ }^{41}$ In Kuwait Petroleum Corporation v I\&D Oil Carriers Ltd (The Houda $)^{42}$ is authority for the proposition that there is no distinction between delivery under a time charter, a voyage charter, or a bill of lading contract and that the carrier cannot be forced to deliver without the bill of lading in the absence of a clause requiring it. It was said that the exceptions in The Sarmovskiy 3068 were doubted in The Houda. ${ }^{43}$ Here, the charterer ordered the carrier to deliver the goods without a bill of lading, against a letter of indemnity countersigned by a bank, but the carrier declined to accept this order. The Court of Appeal rejected the argument that a time charterer could order a carrier to deliver the goods without production of an original bill of lading, even where the consignee was in fact entitled to possession of the goods.

\subsection{Alteration of the Sale Contract}

An early case regarding the carrier's exemption from liability for misdelivery in the event of amendments to the sale contract is The Kota Maju. ${ }^{44}$

40 China Light Industry Crude Materials Corp. $v$ Halian Shipping Co. and Shantou Shipping Agent, "The China Bank"; cited at (2000) Annual of China Maritime Trial, pp. 509-510.

${ }^{41}$ Gaskell et al., p. 425.

42 The Houda [1994] 1 Lloyd's Rep 541.

43 See Gaskell et al., Bills of lading: Law and Contracts (LLP 2000) pp. 422-423.

${ }^{44}$ Hong Kong Resources Textile Crude material Co Ltd $v$ Zhanjiang Shipping Agency and Others, http://www.ccmt.org.cn/hs/news/show.php?cId=1552; or see http://www.cnki.com.cn/Article/CJFDTotal-FYGB199404013. htm.

For a thorough review of this case in English, see Yingying Zou, Delivery of Goods by the Carrier under the Contract of Carriage by Sea- a Focus on China (Ph.D. thesis, Erasmus University Rotterdam 2005) 204. The plaintiff/seller made a contract with Imp. \& Exp. (Group) Co of Shenzhen Specific Zone (the third defendant/buyer) on Sudan crude cotton in 1998. The bill of lading was an order bill with due endorsement of the shipper, and the carrying vessel was The Kota Maju.
Documentary discrepancies in this case caused the bank not to pay the seller. The goods were discharged at the warehouse against a letter of indemnity. The seller negotiated with the buyer on the quality of the goods and received part payment. However, the seller was later informed that the remaining goods had been removed from the port warehouse. The seller was the lawful holder of the bill of lading and the owner of the goods at the time of discharge. The delivery of the goods without a bill of lading violated the presentation rule, breaking the right invested in the bill of lading, and therefore the seller had the right to claim. However, re-negotiation of the payment period under the sales contract and the investigation of the goods by the seller after the discharge was construed by the judge as an alteration of the sale contract. The bill of lading had ceased to be a document of title; ${ }^{45}$ therefore the delivery without the bill of lading was approved. ${ }^{46}$ However, in The Ines ${ }^{47}$, there were different causes of actions and the judge held that the commencement of a lawsuit based on the sale contract did not amount to a waiver of other causes of action depending on the carriage contract.

In a controversial decision, "The Xing Long", the judge of High Court of Tianjin found the carrier not liable for delivery without bill of lading because the holder had claimed against the payment under the sale contract. ${ }^{49}$ However, this approach is open to criticism

\footnotetext{
45 In The Kota Maju, the bill of lading ceased to be a document of title when the seller negotiated with the consignee on the payment of the goods, which occurred after the delivery, and therefore, the seller was not entitled to claim against the carrier under the bill. However, the judge's approach on that the negotiation of the bill after the delivery of goods causes the loss of bill of lading's continuing function of the document of title is subject to debate. In fact, this case can also be an example for the estoppel by conduct.

46 This decision was praised by scholars. See Liu Yan, "On Carrier's Liability for Delivery of Cargo without Production of Original Bill of Lading: The Kota Maju", [1996] Lloyd's Maritime and Commercial Law Quarterly 31.

47 [1995] 2 Lloyd's Rep. 144.

${ }^{48} \mathrm{http} / / /$ www.ccmt.org.cn/hs/news/show/ last access 30 March 2015, cited at Yingying Zou p. 205.

49 In China, the holder of bill of lading may have an option for the remedies under bill of lading or sale contract. If he exercises the rights under one relationship, he loses those
} 
because the delivery against bill of lading is a duty and right for the carrier and breach of the presentation rule entails a risk to be sued for damages. In fact, the presentation rule is needed because it permits the seller to control the goods under international trade by holding on to the bill of lading, which surely suits the demands of commerce. ${ }^{50}$

\subsection{Local Customs and Rules}

Local customs and rules may still play a part in spite of the Maritime Code. Where the goods are compulsorily delivered to the customs or port authorities pursuant to the local laws but no declaration is made to the customs office within the time limit allowed by laws at the discharge port, the goods are confiscated and sold according to law by the Customs Office. $^{51}$

In Zhejiang Ji'engshi Garments Group Corp. v Fancheng International Freight Forwarder ${ }^{52}$ the seller sued the carrier for the price of goods, which released by the carrier without bill of lading. The carrier had parts of the goods returned, but the court determined that the seller was entitled to reject the goods and entitled to get compensation. The holder's rights to reject the delivery are determined by the holder's right to reject the goods under the contract of carriage. But Chinese law needs to be clarified on this.

Article 7 of the aforementioned Provisions of the

related to the other. On this ground delivering the goods to the buyer under the sale contract without the bill of lading was a correct delivery to the right person. The risks under the sales contract, such as the loss of payment of goods, shall not be borne by the carrier. Chinese approach seems to be a mixture of two types of relations that are closely related but independent from each other, cited at Yingying Zou, p. 205.

${ }^{50}$ If the carrier does not deliver the goods to the buyer, the holder of the bill of lading still controls the goods, may get the payment from the buyer, might re-sell or keep the goods as value. So the seller can claim for damage if the goods misdelivered.

${ }^{51}$ George Wang, Forwarder law 2009.

52 Zhejiang Ji'engshi Garments Group Corp. v Fancheng International Freight Forwarder, Ref No. Civil Judgment No. 226 (2001) of the High Court of Shanghai. Also see Zhejiang Ji'engshi Garments Group Corp. $v$ Fancheng International Freight Forwarder, Selected Cases of the People's Court, 2002, 2.
Supreme People's Court on certain Issues concerning the Application of law to the Trial of Cases involving Delivery of Goods without an Original Bill of Lading establishes a rule to clarify this matter for the circumstances that the carrier delivers the cargo to the customs or port authorities - as local regulations may require - then the carrier may be discharged from further liability for any claim for misdelivery ${ }^{53}$ if that was the local custom.

\subsection{Conduct of Consignor or Estoppel}

An approach akin to estoppel ${ }^{54}$ was taken in China Light Industry Crude Materials Corp. v Hualian Shipping Co. and Shantou Shipping Agent ${ }^{55}$, where the plaintiff was at present on discharge and while observing raised no objection during the process of delivery without bill of lading. Therefore, the plaintiff's argument was denied due to his silence which akin to common law principle; estoppel.

A contrary decision was given in a Hong Kong case, Trafigura Beheer BV Amsterdam v. China Navigation Co. $L t d .^{56}$ The holder of the bill of lading concluded an agreement with the person who actually took over the goods. However, this was not taken as an approval of delivery without the bill of lading or a waiver of the claims against the carrier. Similarly, in a case before the English court, The Ines ${ }^{57}$, the plaintiffs sued for the price, against the named consignee and the notify party under the bill of lading, who obtained the goods without presentation of it. The judge held that the

\footnotetext{
${ }^{53}$ Huijie Juo, Miao Li, Reviewing Recent Developments in Chinese Maritime Law, JMLC Vol. 41 No. 3 July 2010 p. 407.

54 Estoppel is the principle that precludes a person from asserting something contrary to what is implied by a previous action or statement of that person or by a previous pertinent judicial determination.

55 China Light Industry Crude Materials Corp. v Hualian Shipping Co. and Shantou Shipping Agent; cited at Jin Zheng-jia (chief editor), Annual of China Maritime Trial, the people's communication press, 2000, pp. 509-510.

${ }^{56}$ Trafigura Beheer BV Amsterdam v China Navigation Co Ltd [2000] HKCFI 1374 (http://www.hklii.hk/eng/hk/cases/hkcfi/2000/1374.html) and Trafigura Beheer BV Amsterdam v. China Navigation Co. Ltd (2000) HKCU 1.

57 The Ines [1995] 2 Lloyd's Rep. 144.
} 
assertion of a claim by the plaintiffs against the receivers of goods on a different basis from that asserted against the carriers does not amount to a waiver or ratification upon which the carriers can rely.

\subsection{Agreements in Advance}

At times, agreements made in advance will also be sufficient evidence for the approval of delivery without a bill of lading and the carrier will then not be liable to the parties of such agreements ${ }^{58}$.

In Shuangyao Co. Ltd. v Xiaogang Industrial Material Co, China Shipping Agent Guangzhou and others $^{59}$, the court rejected the claims by the plaintiff on the ground that the plaintiff had ratified the delivery without bill of lading, so that his losses were from the risks under the co-operative contract but not the delivery by the carrier. ${ }^{60}$

\subsection{Term of Sale Contract}

A special term in the sale contract may influence the duties of the carrier in relation to delivery. In China Bank Hunan Province Branch v. Guangzhou Zhenhua Shipping Ltd. Co. and others ${ }^{61}$ (The China Bank), there was a clause in the sale contract: "All the original documents shall pass through the bank, and the seller shall allow and assist the agent of the buyer in Hong Kong to take the delivery of goods in case there is no bill of lading." The bank was the plaintiff and the judge reached the conclusion that the clause permitted traders to ignore the presentation rule and that the bill of lading would not play a traditional role as document of title, therefore, the carrier was found not liable for delivery without bill of lading. This decision has found some

\footnotetext{
58 Under common law, these agreements or actions by the plaintiff who is the holder of bill of lading give rise to an "estoppel", which may exempt the carrier from the liabilities for the delivery without bill of lading.

59 Shuangyao Co. Ltd. v Xiaogang Industrial Material Co, China shipping Agent Guangzhou and others, see Jin zheng-jia (chief editor), Annual of China Maritime Trial, the people's communication press, 1999 (Jin Zheng-jia 1999), pp. 335-339.

60 Jin Zheng-jia 1999, pp. 335-339.

61 Jin Zheng-jia, 1999, pp. 340-348.
}

support $^{62}$ but can be criticised from a civil law point of view, because the holder of the bill was a third party to the sale contract and immune of any special provision in it unless he should be expected to know that special term. That said, banks always ask for the copy of the sale contract in their letter of credit agreements.

It appears that Chinese judges have been construing the cases before them according to the facts of the each case and interpreting the statutory provisions together with Supreme Court promulgations and releasing their own authentic and distinctive judgments. There is arguably a need for uniformity and advisable that the statutory provisions should meet the application of this lively area of practice.

Right of Action against the Carrier

According to article 41 of the Maritime Code, a contract of carriage of goods by sea is a contract under which the carrier, against payment of freight, undertakes to carry by sea the goods contracted for shipment by the shipper from one port to another. The shipper, certainly, is the contractual party to the contract of carriage and entitled to act against the carrier. There are some Chinese court decisions about the right of action against the carrier. The dispute in Ningbo Electronics Imp. \& Exp. Co. v. NYK $C^{63}$ concerned about a delivery without bill of lading where the seller sued the carrier under an FOB contract. The buyer was the "shipper" and the "consignee" was the third party. According to article 42(3)(a) of the Maritime Code, the person who concludes the carriage contract with the carrier and/or art 42(3)(b) the person by whom or in whose name or on whose behalf the goods have been delivered to the carrier is defined as the "shipper." of the seller who did not enter into a carriage contract

\footnotetext{
${ }^{62}$ Yingying Zou, pp. 206-207.

${ }^{63}$ Ningbo Electronics Imp. \& Exp. Co. v. NYK CO, Research Institute of Ningbo Maritime Court, Selected Maritime Cases, 2001, 11, pp. 89-94, cited at Yingying Zou, p. 213.

${ }^{64}$ In other words, "contractual shipper" refers to the person who has concluded the contract with the carrier (CMC article 42 (3) (a)), and "actual shipper" refers to the person by whom or in whose name or on whose behalf the goods has been delivered to a carrier (CMC article 42 (3) (b)).
} 
with the carrier, despite the fact that the shipper, whose name appeared on the bill, actually was the contractual party of the carriage contract as buyer in accordance with the FOB sale contract. The judge found that the seller was the person who actually sent the goods to the carrier and he was also the shipper within the definition of CMC art 42(3)(b) (the person by whom the goods have been delivered) and entitled to sue the carrier. ${ }^{65}$

In Wenzhou Imp. \& Exp. Co v Qiaoyun International Shipping Ltd ${ }^{66}$ (Helka Express International Ltd) the shipper's right to delivery was protected, in the case of delivery without bill of lading. Here, Wenzhou Import and Export Co was plaintiffs and Qiaoyun International Shipping Ltd was first defendants (referred to as "Hong Kong Qiaoyun"), and Wenzhou Qiaoyun Shipping Agency Ltd was second defendants (referred to "Wenzhou Qiaoyun"), and the actual carrier Huamao Ltd. was the third defendants. There was also another issue raised to the Court in order to make a call for the consignee "BR Import-Export" as the co-defendant for releasing the goods against letter of indemnity. Although the Court accepted that there should be three defendants rejected the application for adding BR Import Export as the co-defendant.

The plaintiff (the consignor)-because the sale contract was on CIF basis-booked a place on board for the carriage of two separate parcels of goods (one 52 items and the other 66 items) for the carriage from Shanghai to Wien. The plaintiffs brought the goods to loading port agent and Wenzhou Qiaoyun signed bills of lading in the name of HongkongQiaoyun, where on itself the plaintiff was consignor, two sets, with three copies each, serial number is ECU00575320 and

${ }^{65}$ It is mentioned that there contrary views of which affirm the right of the suit for the consignor lie on the fact the bill must be issued to the person who sends the goods to the carrier and therefore only the seller is entitled to get the bill form the carrier and sues; For that view see Yingying Zou, p. 214 and fn 42.

66 Judgment of (2002) Yong Hai (maritime division), WenZhou (city name), Chu Zi (first instance court) No. 74, The Theory and Practices of Maritime Jurisdiction, 1st ed., Law Press, 2002, 442-448, cited in Yingying Zou, p. 216; also see http://www.simic.net.cn/news_show.php?lan=cn\&id=14373; also see http://www.ccmt.org.cn/showws.php?id=847.
ECU00575388, consignee indicated by BR Import Export, loading port was Shanghai, discharge port was Wien, the goods were lighters, 52 boxes and 66 boxes each, loading time was 12th and 15th, May, 2000, the ships were "Zhenhe V0079W" and "Mare Gallicum V0005W', freight payment in advance, clause of delivering the goods with any original bills of lading necessarily.

After the goods arrived the destination port, the goods were released without original bills of lading.

The judge was convinced that the bill of lading proved the freight transport relationship between the defendant HongkongQiaoyun and the plaintiff Wenzhou Imp. \& Exp. Co., and HongkongQiaoyun should ensure the goods to be taken with original bill of lading. Defendant HongkongQiaoyun, as carrier, released the goods without consignor approving and non-B/L's holder, should compensate for the losses of goods and interest of plaintiff.

The court considered that bill of lading was still in consignor's hand, it was not put into sales transaction, but it could not change the obligation of carrier to release the goods only with original bill of lading. And HongkongQiaoyun debated that they were not the real carrier causing it had authorized the real carrier to transport the goods and had no fault about releasing the goods without original bill of lading, here, court considered it was a basic obligation for the carrier releasing the goods with original bill of lading, so the Court rejected HongkongQiaoyun's counter argument. And Wenzhou Qiaoyun asked Huamao Ltd. to book the shipping space after accepting plaintiff's authorization to book the shipping space, then Huamao Ltd. finished the task and taken transportation expenses, for this reason, defendant HongkongQiaoyun and Wenzhou Qiaoyun point out that Huamao Ltd. was the actual carrier and should accept the liability of releasing the good without bill of lading, here, court considering the definition of a real carrier is the person who finish the task of freight transport by actual behavior of his own under the authorization of carrier. Even though 
defendant HongkongQiaoyun and Wenzhou Qiaoyun had submitted preliminary evidences about it, they could not prove the fact that Huamao Ltd. finished the task of freight transport by actual behavior himself yet. So, defendant HongkongQiaoyun and Wenzhou Qiaoyun's assertion that Huamao Ltd. should accept the liability of releasing the goods without bill of lading had too less evidences to support by judge. And the dispute between defendant HongkongQiaoyun and defendant Huamao Ltd. may be solved by other way and had no influence to defendant HongkongQiaoyun's liability for releasing the goods without bill of lading as the carrier. And plaintiff's assertion that HongkongQiaoyun did not have the qualification to operate the business of maritime freight transport did not concern this case, however, it should be disposed by the transportation department.

Considering article 9 (b) and article 122 in the Contract Law of PRC, article 60(a), article 71 in the Maritime Code (CMC) and article 64(a), article 130 in the General Principles of Civil Law of PRC, the court ruled out that the defendant Qiaoyun International Shipping Ltd (HELKA EXPRESS INTERNATIONAL LTD) must pay for the losses of payment of goods against the delivery by the carrier without bill of lading.

Another suggestion was made about that if the FOB seller holding the bill is not seen as the shipper on its face he is not entitled to exercise the rights under the bill of lading in maritime law but may sue in civil law as such is the case as tortious cause. ${ }^{67}$ However, this view was debated referring on that the delivery of the goods against the bill of lading is a promise made by the carrier, but the promise is made only against the shipper in the contract of carriage and the legal holder of the bill of lading, but when the person who holds the bill has no right under the document, the carrier should not be bound by this promise. Under this circumstance, the carrier is entitled to deliver the goods in compliance with instructions of the contractual shipper or the consignee. Therefore, the consignor shall not claim on

${ }^{67}$ See Yingying Zou p. 216. the basis of tort against the carrier in most cases ${ }^{68}$.

The outcome should be that of the shipper who is appeared as the shipper on the face of the bill of lading would be entitled to the delivery of the goods when he possesses the bill. If the seller of an FOB contract aims to keep control the goods to avoid remaining unpaid, he must make it sure to be written as the shipper, or the order consignee named on the face of the bill. ${ }^{69}$

The Future-Directions for Development

The new UNCITRAL convention known as the "Rotterdam Rules" 70 regulates electronic transport documents ${ }^{71}$ and contains detailed provisions regarding the delivery of goods in the international carriage of goods by sea. Previous conventions have failed to make rules on the delivery of goods. ${ }^{72}$

The undertaking for the carrier to deliver the cargo to the consignee is first envisaged in article 11 and then in art 13(1). However, detailed references for the delivery of cargo without the bill of lading are made in articles 45, 46 and 47. There are separate circumstances for where there is a non-negotiable transport document issued requiring no surrender; a non-negotiable transport document that requires surrender; and a

68 This view was put forward by Yingying Zou at pp. 216-217.

69 Yuzhuo Si, Monographic Study of Maritime Law, Renmin University of China Press, 2007, p. 172.

70 The United Nations Convention on Contracts for the International Carriage of Goods Wholly or Partly by Sea, 2009, known as the Rotterdam Rules.

71 Rotterdam Rules article 1 (18). "Electronic transport record' means information in one or more messages issued by electronic communication under a contract of carriage by a carrier, including information logically associated with the electronic transport record by attachments or otherwise linked to the electronic transport record contemporaneously with or subsequent to its issue by the carrier, so as to become part of the electronic transport record, that: (a) Evidences the carrier's or a performing party's receipt of goods under a contract of carriage; and (b) evidences or contains a contract of carriage."

72 The acceptance of electronic documents is not a matter of changing transportation law to enable electronic documentation, but is predominantly a matter of gaining the trust and security of the customers who use shipping documents in their trade relations, however, when the data represent negotiable documents that cover valuable assets, an established legal structure is needed; Marek Dubovec, The Problems and Possibilities for Using Electronic Bills of Lading as Collateral, Arizona Journal of International \& Comparative Law, Vol. 23 No. 2, 2006 p. 466. 
negotiable transport document that again requires surrender unless expressly stipulated otherwise.

Where there is no negotiable transport document or a negotiable electronic transport record has been issued, the carrier may deliver the goods without the bill of lading to the consignee ${ }^{73}$ at the time and location agreed in the contract of carriage or which, having regard to the terms of the contract, the customs, usages or practices of the trade and the circumstances of the carriage ${ }^{74}$. That usage of customs of port and/or local practice is in fact a reality in Chinese provinces. The carrier, by following the instructions given to him by the shipper, can be relieved of his obligation to deliver to the consignee and will be indemnified by the shipper who gave the instructions for his liability with regards to the holder of the document of transport.

When a non-negotiable transport document has been issued, indicating that it is to be surrendered to obtain delivery of goods, the carrier may deliver the goods to the consignee ${ }^{75}$ upon the consignee identifying itself and surrender of the non-negotiable document at the time and location agreed in the contract of carriage or which, having regard to the terms of the contract, the customs, usages or practices of the trade and the circumstances of the carriage. ${ }^{76}$ This is a reflection of the usage of sea way bills legitimising the current practice.

When a negotiable transport document or a negotiable electronic transport document has been issued, the holder of the negotiable document or non-negotiable electronic transport record ${ }^{77}$ is entitled

\footnotetext{
73 Rotterdam Rules, art 45.

74 Rotterdam Rules, art 43.

75 Rotterdam Rules, art 45.

${ }^{76}$ Rotterdam Rules, art 46.

77 Rotterdam Rules art 8: Use and effect of electronic transport records are subject to the requirements set out in this Convention: (a) Anything that is to be in or on a transport document under this Convention may be recorded in an electronic transport record, provided the issuance and subsequent use of an electronic transport record is with the consent of the carrier and the shipper; and (b) The issuance, exclusive control, or transfer of an electronic transport record
}

to claim delivery of the goods from the carrier, at the time and location agreed in the contract of carriage or which, having regard to the terms of the contract, the customs, usages or practices of the trade and the circumstances of the carriage. ${ }^{78}$ The first part (article 47(1)) refers to "surrender' of the transport document, therefore the presentation rule applies. However, article 47(2) goes on to set out contains an innovation of designed for the situation where the holder of the bill cannot ask for delivery or cannot prove his identity in a proper manner or the carrier cannot locate the holder of the bill. The carrier is to ask for the instructions of the shipper in such circumstances. ${ }^{79}$ This is particularly the case where a time charterparty is in operation and charterers are inclined to instruct the master to deliver the cargo to the named person without bill of lading. This practice is recognised by the courts as long as there exists a charterparty. ${ }^{80}$ However, in bill of lading contracts the situation might be different since the shipper may not be in a position to know who the ultimate consignee is because of in transit re-sales. ${ }^{81}$ Therefore, it is suggested that the carrier should ask, the notify party who is showed on the bill instead the shipper since the notify party would be in better position to have the information about the latest consignee. $^{82}$

Article 47(2) has been the subject of different

has the same effect as the issuance, possession, or transfer of a transport document.

78 Rotterdam Rules art 47/(1).

79 It has been said that the drafters were influenced by the practice of charterers acting as shippers and the carrier following the instructions of the charterer/shipper; Delivery of the Goods under the Rotterdam Rules: Departure from the Fundamental Principles, Universidad Nacional Autonoma de Mexico 2013 (Caslav Pejovic), p. 299; http://biblio.juridicas.unam.mx/libros/8/3581/21.pdf; last access on 21.03.2015 16.46.

80 The Houda, above.

${ }^{81} \mathrm{RR}$ aim at bill of lading contracts (art 1.3) not charterparties (art 6.1), therefore asking the shipper who the true receiver would be turns out to be somewhat useless.

${ }^{82}$ Dr. Pejovic points out that the shipper might not be the charterer and asking the shipper for instructions might lead to a contradictory for the principle on negotiable transport documents, Caslav Pejovic, p. 300, http://biblio.juridicas.unam.mx/libros/8/3581/21.pdf last visited on 21 March 2015 16. 46. 
interpretations. It has been claimed that the holder must still possess the bill but need not surrender the same, ${ }^{83}$ but the objection to that interpretation ${ }^{84}$ is that the provision may apply in case there appears to be no bill at the time of the delivery. It was suggested that if it were possible to deliver the goods without surrender, the security function of the negotiable bill would be undermined $^{85}$.

It must be pointed out that the carrier can always request to be comforted with a guarantee before carrying out the shipper's instructions. ${ }^{86}$ A usual LOI would fit well into the matrix of this provision, indicating that the convention recognises the common practice.

China has not signed or ratified the Rotterdam Rules, however, it is said to be in favour of the purposes and underlying principles thereof; the regime regarding transport documents and electronic transport records; the provisions regarding identification of carrier; the rights and obligations of carrier, performing party and shipper and those relating to multimodal transport; and rights of control. ${ }^{87}$ It has also been suggested that adoption of the provisions regarding electronic transport records and multimodal transport seem helpful to improve the hybrid regime in the Maritime Code in order to meet the rapid use of electronic commence in the maritime transport and the rapid development of multimodal transport of containerised goods. ${ }^{88}$ The use of electronic transport documents in the future may reduce the disputes in the events of delivery without bill of lading, but it advisable to contain explicit provisions to govern the interests of the shipper (including an FOB seller), the carrier or actual carrier, the consignee who is entitled to take delivery of goods and the actual cargo receiver who took delivery

\footnotetext{
83 Caslav Pejovic, p. 303.

84 Caslav Pejovic, p. 303.

85 Caslav Pejovic, p. 304.

${ }^{86} \mathrm{RR}$ art $47 /(2)(\mathrm{c})$.

87 James Zhengliang Hu (James Hu), A Study on the revision of the Chinese Maritime Code, East Asia Maritime Law Forum, 8-9.11. November 2014, Japan, p. 9.

${ }^{88}$ James Hu, p. 10.
}

of goods. $^{89}$

Practical Advice

In the recent case of Sang Stone Hamoon Jonoub Co Ltd v Baoyue Shipping Co Ltd (The BaoYue) ${ }^{90}$, judge ruled on the potential liability of cargo owners to shipowners where they do not take delivery of the cargo and the compensate such shipowner who might expect in return. In this case, the unpaid FOB seller of the goods (who held the bills of ladings) was found liable to the shipowner for stowage charges greater than the value of the unpaid cargo. Although the significant outcome of this case is clarifying the liability of the bill of lading holder who has not turned out to receive the cargo from the carrier there is another essential view of the judge released by this decision. This case would suggest the carrier could invoke a contractual clause indicating that the carrier may be deprived of any liability against the delivery of the cargo without presentation of the bill of lading.

The claimant seller was the shipper of iron ore onboard the defendant shipowner's vessel, the "BaoYue", from Bandar Abbas in Iran to Tianjin in China in 2012. The bill of lading, in this case, incorporated the terms of the applicable voyage charterparty, including that: (i) the shipowner was entitled to discharge the cargo "to custom bonded warehouse area against Charterer's single LOI”; and (ii) "in the event cargo being kept in warehouse in lieu of waiting for [original bill of lading] to arrive at the discharge port, the expense of warehouse and all relevant costs to be for Chrtrs' account...".

Discharge of the cargo upon the vessel's arrival, no bill of lading was presented, it still being locked in the seller's safe in Iran, since there occurred a dispute between the parties: the total price of the "BaoYue" cargo was US\$ 1.2 million, of which some $70 \%$ had already been paid to the seller by the buyer, leaving a

\footnotetext{
${ }_{90}^{89}$ James Hu, ibid.

([2015] EWHC $2288 \quad$ (Comm)), http://www.reedsmith.com/A-timely-lesson-understanding-how -a-sale-contract-dispute-may-have-serious-financial-consequen ces-beyond-that-contract-alone-08-17-2015/.
} 
balance of approximately US $\$ 330,000$. The bill of lading was issued but, instead of being sent to the buyer, was retained by the seller in Iran due to the claim raised by the seller being unpaid in full.

The cargo secured in a warehouse by the shipowner and over three years after the cargo was discharged, the seller had reportedly had no contact with the warehouse owner or any recent contact with the buyer. The seller did not ask for delivery of the cargo or seek to inspect it, nor did the buyer ever attempt to remove the cargo from storage, despite being prompted to do so by the defendant shipowner.

The seller's claim against the defendant shipowner for unlawful conversion of the cargo was based on "conversion ${ }^{91}$ by the creation of a lien" and "conversion by denial of access". However, the court rejected the seller's claim for damages for conversion; (i) there would be a declaration that the seller is liable to reimburse the defendant shipowner for reasonable storage charges as and when they are paid to the warehouse owner; and (ii) the seller must deliver the original bill of lading to the defendant shipowner to enable the cargo to be sold. The "BaoYue" although demonstrates that buyers and sellers involved in a dispute under a sale contract risk becoming liable for charges exceeding the value of the cargo if they do not take action to resolve and mitigate the consequences of such dispute, it also demonstrates that the clause in the charterparty can be incorporated in the bill of lading and therefore the carrier can rely on this clause and deliver the cargo without production of bill of lading to a warehouse with a full confidence that the expenses would be payable by the seller who has not release the bill of lading into circulation. Hence shipowners/carriers are well advised of stipulating such clauses entitling them to handover the cargo at the discharging port if there appears to be no bill of lading presented.

91 Conversion occurs when a person deliberately deal with goods in a way which is inconsistent with another person's right to those goods and which deprives that other person of the use and possession of those goods.

\section{Conclusion}

China is a leading economic power, but it must continue to improve its laws and legal system if it hopes to also maintain a prominent position as a legal and social power. After the establishment of the specialist courts the worry about the reliable decisions among the foreign companies has been satisfied to some degree. Most academics with knowledge of English common law may try to find the answers and developments from recent Chinese maritime cases. However, there is no concept of precedent from case law in China. In theory, each case stands as its own decision and will not bind another court; although interpretations issued by the Judicial Committee of the Supreme People's Court act as a guide to later cases. A new approach for a strong internal regulatory unification should assist China's advancement.

Delivery of the goods without presenting the bill of lading is common in Chinese practice and may bring risks to both the traders and carriers. The means to resolve this practice can be based on two approaches: "speeding up" the circulation of bills of lading, and "giving up" presentation on delivery by an innovative system of transport documents. The adaptation of related principles into the future revision of the Chinese Maritime Code would have positive effects, such as a legalisation of the electronic bill of lading and use of non-negotiable documents as a solution for the delivery of goods without bill of lading issues, as well as careful consideration of the approaches of comparable legislation in other jurisdictions as well as the Rotterdam Rules to the related issue. Well drafted carriage contract terms might assist the shipowner/carrier to escape the liabilities against non-presentation of bill of lading at the discharge port.

The future Maritime Code may again establish the carrier's obligation to deliver the cargo to the person in accordance with the contract. However, it may need to identify the person to whom the delivery must be made 
under various documents, such as bill of lading, sea waybill, or other electronic transport documents. Solutions should be in place for the carrier and the consignee when they face adverse or competing claims. Under these circumstances, the carrier is bound not to infringe the rights or title to the goods, so the contractual rule on delivery may be abandoned. Additionally, the interpleading procedure may be approach for them. Furthermore, being related closely to delivery, the provisions on controlling rights also need elaboration. A comprehensive system including the categories of the rights of control the controlling party, the exercising of such right under different transport documents, the conditions for such rights and the transfer or cease of such rights, will be very helpful to identify confusion arising in Chinese practice and achieve a better standard of dispute resolution. 